\title{
Agroecological zoning and land suitability assessment for maize (Zea mays L.) development in Buton regency, indonesia
}

\author{
Aminuddin Mane Kandari ${ }^{1}$, Sumbangan Baja ${ }^{2}$, Ambo Ala ${ }^{3}$, Kaimuddin ${ }^{3}$ \\ ${ }^{1}$ Department of Agrotechnology, Faculty of agriculture, Haluoleo University, Kendari, Southeast Sulawesi, Indonesia \\ ${ }^{2}$ Department of Soil Science, Faculty of agriculture, Hasanuddin University, Makassar, South Sulawesi, Indonesia \\ ${ }^{3}$ Department of Agronomy, Faculty of Agriculture, Hasanuddin University, Makassar, South Sulawesi 90245 Indonesia
}

\section{Email address:}

manekandaria@yahoo.com (A. M. Kandari),sbja02@yahoo.com.au (S. Baja),amboala_aa@yahoo.com (A. Ala), kaimuddin@yahoo.com (Kaimuddin)

\section{To cite this article:}

Aminuddin Mane Kandari, Sumbangan Baja, Ambo Ala, Kaimuddin. Agroecological Zoning and Land Suitability Assessment for Maize (Zea mays L.) Development in Buton Regency, Indonesia. Agriculture, Forestry and Fisheries. Vol. 2, No. 6, 2013, pp. $202-211$.

doi: $10.11648 /$ j.aff.20130206.11

\begin{abstract}
From a regional planning perspective, information on agroecological zones, land characteristics and its suitability for a certain land use type is needed for more efficient land management decisions. The main aim of this paper is to assess land characteristics and to evaluate land suitability for maize cultivation on a regional basis. This research was conducted from August 2012 to February 2013 on 10 locations (sub-districts), in the main land of Buton Island, Indonesia, namely: Batauga, Sampolawa, Lapandewa, Wabula, Pasarwajo, Wolowa, Siontapina, South Lasalimu, Lasalimu, and Kapontori. Three main stages were undertaken in this study: survey, mapping, and evaluation, to assess land suitability for maize development. Land suitability map for maize was developed in GIS, based on such parameters as climate (air temperature, air humidity, and rainfall), soils (texture, $\mathrm{pH}, \mathrm{C}$-organics, clay $\mathrm{CEC}$, drainage, and erosion condition), and physiography (topography, landform, and altitude). Land suitability classes were grouped into very suitable (S1), moderately suitable (S2), marginally suitable (S3), currently not suitable (N1), and permanently not suitable (N2). The results show that due to severe limiting factors, suitable land (class S3) covers only a total area of $509.60 \mathrm{ha}$, or only $0.64 \%$ of the total potential area for development $(74,664 \mathrm{ha})$. This was mainly located in Sampolawa sub-district 405.34 ha (0.54\%) and Kapontori 104.26 ha $(0.14 \%)$. Other locations in general, fall into permanently not suitable class $(\mathrm{N} 2)$ with a total area of $61,113.08(81.85 \%)$, where the largest area was found in Pasarwajo 12,616.68 (16.90\%); and currently not suitable class (N1) covers only 13,042.01 ha (17.47\%), where the largest area was in South Lasalimu 6,5459.23 ha $(8.32 \%)$. This research may be useful as references for efficient spatial decision making in the allocation of maize in the region.
\end{abstract}

Keywords: Agroecological Zoning, Land Suitability, Maize, GIS, Buton Regency

\section{Introduction}

Maize is one of the important food crops in Indonesia, because it is not only as the second staple food crop besides rice, but also as the substance for feeding the livestocks. However, the facts showed that maize production has recently declined as productive cultivation areas for maize are also reduced. This is, in parts, as a consequency of regional development, where productive land is transformed into settlements, buildings and other non-agricultural facilities. Moreover, agricultural developmental areas are not suitable for their uses, actually and potentially.
Buton regency is one of the regions in Southeast Sulawesi potentially facing food scarcity, due to its dry climate conditions (rainfall $<2000 \mathrm{~mm} \mathrm{y}^{-1}$ ), complex topography and low fertility land. Moreover, local people have recently tended to left-behind local foods and consume more ricebased foods. Buton regency has main-land area of 248,871 ha with the population of 255,712 ; therefore it is still potential for maize cultivation in some locations. This is also because the region not only has great potential dry land area, which is around $74,664.67$ ha $( \pm 30 \%)$, but also most of the people in the region $(176,441)$ are farmers $( \pm 69 \%)$ with the main staple food is maize [11]. Baja [7] confirmed that Buton regency is a part of the Great Buton that is potential 
for crop development especially maize. Never theless, so far only about $10-15 \%$ of potential land has been used to grow maize and other local food crops.

As pointed out in [23], the use of unsuitable land can decrease productivity, quality, and eventually its sustainable use. Similarly [25] previously also stated that suitability of agroecologic requirements is fundamental for crop cultivation; otherwise it causes not only economical and financial losses, but also generatis social costs, in forms of degradation of and declining in the quality of land resources. Djaenuddin [13] also mentioned that soil mapping and land evaluation are effective approaches to determine spatially land potential, including its limitations, as well as inputs, and management. Baja [6] explained that the optimal utilization of land resources based on its capacity can only be conducted when the information on the land suitability is available on each development region. Land evaluation is required to determine the land suitability for plant growth. Land evaluation is conducted based on the information on soil conditions (physical, chemical, and soil microbiological properties), and climatic conditions (air temperature, air humidity, and rainfall).

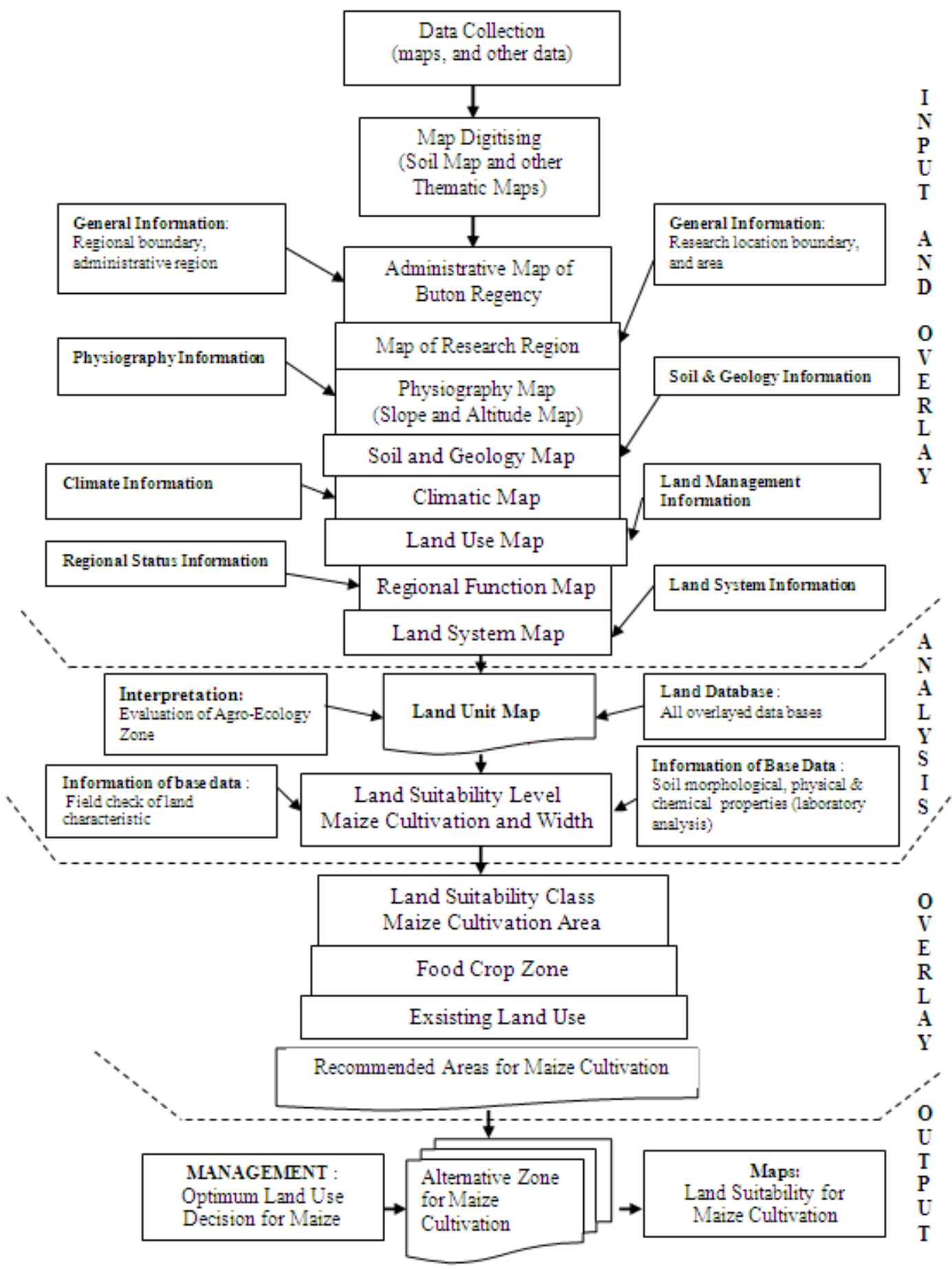

Figure 1. Diagram of Research Method 
Therefore, agroecological conditions of a region must be carefully identifical as the prerequisites for planning and cultivation of agricultural products. Baja [6] stated that one of the alternatives to optimalize land use is through appropriate land use planning, by considering a number of factors especially biophysic characteristics using GIS technology. With this technology, complete and up-to-date information on land suitability can be obtained. Baja [8] also mentioned that the application of GIS can fasten the development of working-map and land mapping unit, which are always required to support decision making on optimum location-based land use.

As noted in [5], one of the limiting factors in conducting agriculture development in a certain region such as Buton is the unavailability of data (especially spatial data), despite the fact that the region is actually potential to support sustainable crop production.

Based on the above information, it reguires a study on the agroecological zonation for maize cultivation in Buton regency. The objectives of this study were: (i) to assess biophysic characteristics and land suitability for maize cultivation, (ii) to determine limiting factors and technology input alternatives for land use to increase maize productivity. This research employs GIS for mapping processes and some analytical procedures.

\section{Study Area}

Buton regency is situated in the southeastern part of Sulawesi Island, Indonesia, and geographically located between $4.96^{\circ}$ and $6.25^{\circ}$ South Latitude and $120.0^{\circ}$ and $123.34^{\circ}$ East Longitude. This research was conducted on 10 sub-districts out of 21 sub-districts in Buton regency, including Batauga, Sampolawa, Lapandewa, Wabula, Pasarwajo, Wolowa, Siontapina, South Lasalimu, Lasalimu, and Kapontori.

\section{Methodology}

This research utilizes primary and secondary data. Primary data collected were soil physical, morphological, and chemical properties on each site (mapping unit), analysed in the Soil Laboratory of Hasanuddin University, Makassar. Secondary data include: (1) soil map, with scale of 1 : 50,000, (2) land use map of Southeast Sulawesi, with scale of $1: 25,000$, (3) administrative map of Buton regency, and other thematic maps derived from satellite data, each with scale of $1: 25.000$, and (4) regional climatic data over the last 10 years (2002-2011) from several climatic and rainfall stations in the region and surrounding areas [9];[10].

The research employs a spatial analysis method, using the ArcView GIS software. The research was conducted in three main: (1) survey, (2) evaluation, and (3) mapping. These three main steps were performed in five stages: (a) preparation, (b) collection of land biophysic data (physiography, land and climate), (c) input and data analysis, (d) interpretation for land evaluation, and (e) development of land suitability map for maize (Figure 1).

Figure 1 shows the schematic diagram of research activities. At the early stage, preparation was conducted to collect data and information on secondary and primary data. Secondary data were directly collected from the sources, while primary data were collected using survey method and interview, either directly or through questioners. Land biophysic data were directly collected in the field on each research site, based on technical guidelines provided by the Research Center for Soil and Agroclimate [27]; [26]; [19]. Method for soil sampling and analysis was based on Soil Survey Staff [29]; [30].

Subsequent stage was data input and tabulation, according to the format of analysis for secondary and primary data. Next stage was data interpretation for final use, and followed by verification to enable the data ready for analysis. Data analysis was conducted to determine the suitability of maize cultivation to each research site, based on the method of [12]. Final stage of the research activity was the development of suitability map on the research region, with the scale of 1 : 100.000, using GIS method. The land suitability classes were grouped into very suitable (S1), moderately suitable (S2), marginal suitable (S3), currently not suitable (N1), and permanently not suitable (N2) [14].

\section{Result and Discussion}

\subsection{Climatic Conditions}

Three climatology stations were identified on the research region and its surrounding areas: Betoambari, Kaisabu, and Kapontori stations. There was also one rainfall station, namely Lawele station, observing only rainfall but equipped with air temperature and humidity apparatuses. Characteristics of the stations and climatic conditions are shown in Table 1 and Fig. 2, respectively.

Table 1 shows that four climatology stations had different geographical positions (latitude, longitude and altitude) implying the differences in the climatic characteristics. It depicts the values of observed climatic characteristics in each station during the last ten years (2002-2011), except for radiation and evaporation data in Lawele station, which were based on an empirical approach. The number of consecutive wet months and dry months was varied, so that the climatic type based on Oldeman method [21] was also varied. Furthermore, the average yearly rainfall of $<2000 \mathrm{~mm}$ recorded on all stations indicates that the research region was classified into a dry climate. Analysis results on each climate component and its coverage was shown in Fig. 2. 
Table. 1. Climatic conditions in the study area

\begin{tabular}{|c|c|c|c|c|c|c|c|c|c|c|c|c|c|}
\hline \multirow{3}{*}{$\begin{array}{l}\text { Station } \\
\text { Name }\end{array}$} & \multicolumn{3}{|c|}{ Geography Position } & \multirow{3}{*}{$\begin{array}{c}\text { RS } \\
\begin{array}{c}\mathrm{Cal} / \\
\mathrm{cm}^{2} / \mathrm{d}\end{array}\end{array}$} & \multirow{3}{*}{$\begin{array}{c}\mathbf{T} \\
{ }^{\circ} \mathbf{C}\end{array}$} & \multirow{3}{*}{$\begin{array}{l}\text { RH } \\
\%\end{array}$} & \multirow{3}{*}{$\begin{array}{c}\text { Eo } \\
\text { mm } \\
\text { mth }^{-1}\end{array}$} & \multirow{3}{*}{$\begin{array}{l}\text { Rainfall } \\
\mathbf{m m ~ y}^{-1}\end{array}$} & \multicolumn{2}{|c|}{ C.Number } & \multirow{3}{*}{$\begin{array}{c}\text { Oldeman } \\
\text { Climate } \\
\text { Type }\end{array}$} & \multirow{2}{*}{\multicolumn{2}{|c|}{ Coverage Area }} \\
\hline & Latitude & Longitude & Alt & & & & & & WM & DM & & & \\
\hline & SL & EL & m dpl & & & & & & mnth & mnth & & Ha & $\%$ \\
\hline Betoambari & $05^{\circ} 02^{\prime} 55^{\prime \prime}$ & $122^{\circ} 34^{\prime} 13^{\prime \prime}$ & 47 & 404 & 27.0 & 82 & 221.3 & $1,989.7$ & 5 & 4 & $\mathrm{C} 3$ & $9,905.72$ & 4.72 \\
\hline Kaisabu & $05^{\circ} 28^{\prime} 27^{\prime \prime}$ & $122^{\circ} 41^{\prime} 13^{\prime \prime}$ & 250 & 424 & 27.9 & 94 & 196.1 & $1,747.2$ & 5 & 4 & $\mathrm{C} 3$ & $68,014.50$ & 32.38 \\
\hline Kapontori & $05^{\circ} 13^{\prime} 05^{\prime \prime}$ & $122^{\circ} 48^{\prime} 22^{\prime \prime}$ & 70 & 400 & 28.1 & 83 & 194.6 & $1,552.4$ & 2 & 4 & E3 & $46,352.70$ & 22.10 \\
\hline Lawele & $05^{\circ} 13^{\prime} 38^{\prime \prime}$ & $122^{\circ} 56^{\prime} 41^{\prime \prime}$ & 3 & 379 & 29,1 & 87 & 167.4 & $1,645.5$ & 3 & 4 & D3 & $85,761.64$ & 40.80 \\
\hline
\end{tabular}

Source: Calculated from secondary data, 2012.

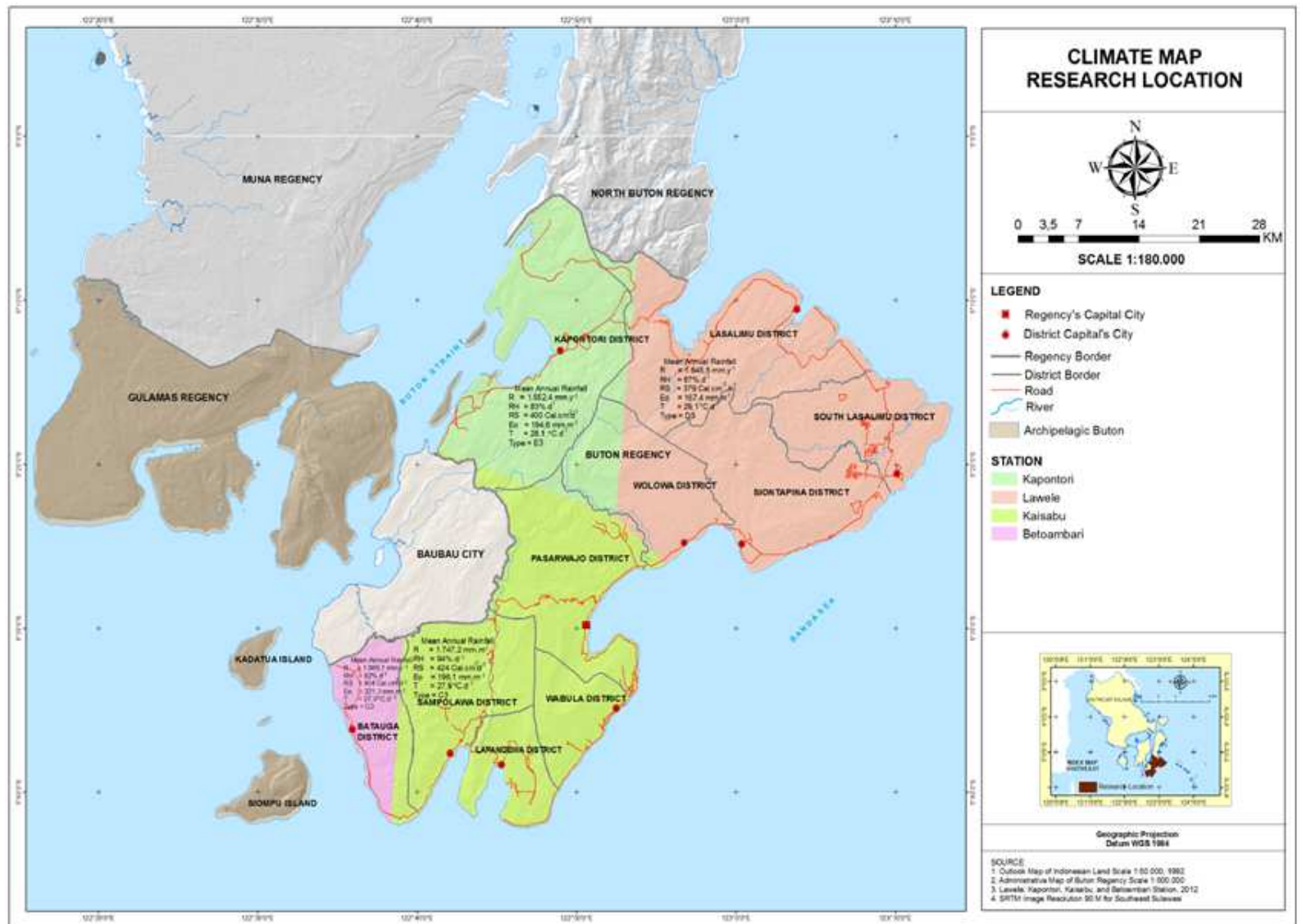

Figure 2. Distribution of climatology stations and climatic conditions in the study area and surrounding regions

\subsubsection{Radiation}

Analysis results show that there are four radiation intensity ranges over the research region: $379,400,404$, and 424 cal $\mathrm{cm}^{-2} \mathrm{~d}^{-1}$; and in general each research site has more than one radiation intensity range, where there are the same intensity ranges over certain research locations but with different coveraged areas. The highest radiation intensity range (424 cal $\mathrm{cm}^{-2} \mathrm{~d}^{-1}$ ) occurres in almost all research locations except in Siontapina, South Lasalimu and Lasalimu. The highest coverages area was in Pasarwajo (24,261.98 ha) and the lowest was in Kapontori (1,247.50 ha). The lowest radiation intensity range $\left(379 \mathrm{cal} \mathrm{cm}^{-2} \mathrm{~d}^{-1}\right)$ occurres in almost all research locations except in Batauga, Sampolawa, Lapandewa, and Wabula. The highest coveraged area was in
Lasalimu (30,992.75 ha) and the lowest was in Kapontori (75.44 ha).

\subsubsection{Temperature}

Each research location in general has more than one air temperature ranges out of four temperatures ranges observed over the research region $\left(27.0,27.9,28.1\right.$, dan $29.1^{\circ} \mathrm{C}$ ), except in Lapandewa and Wabula which has only one air temperature range $\left(27.9^{\circ} \mathrm{C}\right)$ but with different coverage areas: 9,245.07 ha for Lapandewa and 9,465.18 ha for Wabula. The highest air temperature range $\left(29.1^{\circ} \mathrm{C}\right)$ occurres in almost all research locations except in Batauga, Sampolawa, Lapandewa, Wabula, and Kapontori.

\subsubsection{Humidity}

In general, each research location has more than one air 
humidity ranges, out of four humidity ranges observed over the research region $(82,83,87$, dan 94\%), except for Lapandewa, Wabula, Siontapina and South Lasalimu. The highest air humidity range (94\%) occurred in almost all research locations except in Siontapina, South Lasalimu, and Lasalimu. The highest coveraged area was in Pasarwajo $(24,261.75 \mathrm{ha})$ and the lowest was in Wolowa (390.91 ha). Meanwhile, the lowest air humidity range (82\%) occurred only in 2 (two) research locations, Batauga $(9,861.69$ ha) and Sampolawa (44.03 ha).

\subsubsection{Rainfall}

There were four yearly rainfall categories over the research region $(1,552.40,1,645.50,1,747.20$, and $1,989.70$ $\left.\mathrm{mm}_{\text {year }}{ }^{-1}\right)$. Almost all research locations had more than one yearly rainfall ranges, except in Lapandewa, Wabula, Siontapina, and South Lasalimu there had only one rainfall range with different coveraged areas. The highest yearly rainfall range $(1,989.70 \mathrm{~mm})$ occurred only in Batauga and Sampolawa, with coveraged areas of 9,861.69 ha and 44.03 ha, respectively. Meanwhile, the lowest rainfall range $(1,552.40 \mathrm{~mm})$, occurred in Pasarwajo, Wolowa, Lasalimu, and Kapontori, with the highest coveraged area was in Kapontori (37,128.36 ha) and the lowest was in Pasarwajo (922.97 ha).

\subsubsection{Evaporation}

Analysis results of monthly evaporation data showed that there were four evaporation ranges over the research region (167.4, 194.6, 196.1 and $\left.221.3 \mathrm{~mm} \mathrm{month}^{-1}\right)$. In general, all research locations had more than one ranges, except in Sampolawa, Lapandewa, Wabula and South Lasalimu each had one evaporation range with different coveraged areas. The highest monthly evaporation range $(221.3 \mathrm{~mm})$ was in Batauga (861.69 ha) and Siontapina (44.03 ha). While the lowest range $(167.4 \mathrm{~mm})$ occured in all locations except in Batauga, Lapandewa, and Wabula, where the highest coveraged area was in Lasalimu (30, $992.75 \mathrm{ha})$ and the lowest was in Kapontori (75.44 ha).

\subsubsection{Climate Type}

Accumulation of all climate conditions, particularly monthly rainfall, creates a certain climate type. Based on the method of Oldeman [12]), there were three climate types over the research region: C3, D3 and E3. The three climate types occurred in Pasarwajo, Wolowa, and Kapontori but with different coveraged areas. In Lasalimu there were only 2 climate types, also with different coveraged areas. Climate type ranges with the highest number of consecutive wet months (5 months) was type $\mathrm{C} 3$, occurred in all research locations except in Siontapina, South Lasalimu, and Lasalimu, with the highest coveraged area was in Pasarwajo (24,261.98 ha) and the lowest was in Wolowa (390.91 ha). Meanwhile, Oldeman climate type with the lowest number of consecutive wet months (2 months) was type E3, occurred in Pasarwajo, Wolowa, Lasalimu, and Kapontori, with the highest coveraged area was in Kapontori $(37,128.36$ ha) and the lowest was in Pasarwajo (922.97 ha).

\subsection{Analysis of Land Characteristics}

\subsubsection{Landform}

Interpretation of satellite data and field observation show that there were five landforms categories on the research region, namely: Hill system $(\mathrm{H})$; Piedmont Land $(\mathrm{P})$; Uplifted limestones (C); Aluvium Land (A); and Marine Territory (B). Analysis results show that all research locations have more than 3 (three) landform categories, with different coverage areas. Landform category with the highest coverage area is hill system $(\mathrm{H})$ 130,727.86 ha (62.24\%), occured in all research locations, with the highest coverage area was in Kapontori $(26,401.28$ ha) and the lowest was in Lapandewa $(3,436.59$ ha). Meanwhile, landform category with the lowest coverage area is marine territory (B), occupied around 4,440.52 ha $(2.11 \%)$, found in most research locations except in Batauga, Sampolawa, Wabula, Pasarwajo, and Wolowa. For this landform, the highest coverage area was in Lasalimu (1,965.36 ha) and the lowest was in Kapontori (161.26 ha).

\subsubsection{Geology}

Field observation of geological formation on research locations was relevant to the interpretation results of satellite images and regional geological map, in which the geological formation in the research region was relatively complex and they were gouped into eleven formations: Aluvium (Al); limestones (Bg); Ogena $(\mathrm{Og})$; Rumu (Rm); Sampolakosa (Sm); Tobelo (Tb); Tondo (Td); Ultrabasa Kanpa (UbKp); Ultramafik (Uf); Wapulaka (Wp); and Winto (Wt). The coveraged areas of each formation were diversed among research locations. Geological formation with the highest coverage area was Wapulaka (Wp) 70,685.11 ha (33.65\%), found in all research locations with the highest area is in Kapontori $(14,503.20 \mathrm{ha})$ and the lowest in Siontapina (2,989.35 ha).

\subsubsection{Slope}

The slope ranges on the research region are varied, grouped into seven classed : $<2 \% ; 2-8 \% ; 9-15 \% ; 16-25 \%$; $26-40 \% ; 41-60 \%$; and $>60 \%$. Slope range with the highest coverage area is $41-60 \%$, covering $116,391.47$ ha $(55.42 \%)$, and existed in all research locations, in which the highest coveraged area was in Pasarwajo $(21,878.01 \mathrm{ha})$ and the lowest was in South Lasalimu (4,177.61 ha).

\subsubsection{Soil Type}

Soil types in the research region are also varied, and grouped into seven types: hydraquents, rendolls, dystropepts, eutropepts, tropaquepts, tropudalfs, and tropudults. Soil type with the highest coverage area is rendolls, occupied over $82,270.34$ ha areas $(39.17 \%)$, and existed in all research locations, with the highest coveraged area was in Pasarwajo (20,804.88 ha) and the lowest was in South Lasalimu (879.51 ha).

\subsection{Land Use}

Land use is a dynamic and constantly changing entity. Interpretation results of satellite data and field observation 
revealed that there are extremely diversed land uses over the research region, and they were classified into ten categories, namely: primary forest (htpr); secondary dry forest (htlksk); dry land agriculture (ptlk); dry land agriculture mixed with bushes (ptlkcs); savanna (sv); bushes (smb); swamp bushes (smbr); opened land area (tnt); mangrove (mv); and settlement (pk). In Wolowa, there were only 4 land use categories are found: $\mathrm{HtPr}$ (primary forest); Htlksk (secondary dry forest); Ptlkcs (dry land agriculture mixed with bushes); and $\mathrm{SmB}$ (bushes). Land use category with the largest coveraged area was Htlks (secondary dry forest), occupied over $80,667.79$ ha areas $(38.40 \%)$, existed in all research locations, with the highest coveraged area was in Lasalimu (20,506.81 ha) and the lowest was in Lapandewa (619.73 ha). Meanwhile, land use category with the lowest coveraged area was Smbr (swamp bushes), occupied around 236.80 ha areas $(0.11 \%)$, and existed in Siontapina (236.80 ha).

\subsection{Laboratory Analysis of Soil Characteristics}

Soil samples from research locations were analysed in the Soil Laboratory, Faculty of Agriculture, University of Hasanuddin, Makassar. Soil characteristics analysed included physical and chemical properties: texture of 3 fractions (sand, dust, and clay), $\mathrm{pH}\left(\mathrm{pH} \mathrm{H}_{2} \mathrm{O}\right.$ and $\left.\mathrm{KCl}\right), \mathrm{C}$ organic, $\mathrm{N}$ total, $\mathrm{P}$ potential $\left(\mathrm{P}_{2} \mathrm{O}_{5} \mathrm{HCL} 25 \%\right)$, K potential $\left(\mathrm{K}_{2} \mathrm{O}\right.$ HCL $\left.25 \%\right)$, $\mathrm{P}$ available ( $\mathrm{P}$ Olsen or $\mathrm{P}$ Bray I), exchangeable bases ( $\mathrm{Ca}, \mathrm{Mg}, \mathrm{K}$, and $\mathrm{Na}$ ), cation exchange capacity (CEC), base saturation, and exchangeable Al. Methods for soil sample analysis were based on Soil Survey Laboratory Staff (1991) and Soil Survey Staff (2010). These analysis results were used for soil classification, interpretation of soil fertility, determination of soil suitability and its limitations for development.

\subsection{Agroecological Zoning for Maize Cultivation}

Results for land units analysis and map of agroecological zonation for maize cultivation at 10 research locations (subdistricts) in main land of Buton regency were showed at map in Fig. 3.

Fig. 3 shows there are 12 agroecologycal zones in main land of Buton regency, especially at research location, where are the each location have not the same zone total, i.e : Batauga (Iax2, IIax2), Sampolawa (Iax2, IVax1, VIax1), Lapandewa (Iax2, VIax1), Wabula (Iax2), Pasarwajo (Iay2, Iax2), Wolowa (Iay2, Iax2, IVay2), Siontapina (Iay2, IIay2, IIIay2, IVay1, IVay2, VIay1), Lasalimu Selatan (Iay2, IIay2, IIIay2, IVay1, IVay2, VIay1), Lasalimu (Iay2, Iax1, IIay2, IIIay2, IVay1, IVax2, VIay1), Kapontori (Iax2, IIIax2, IVax1, IVax2, VIax1). Besade its, the each agroecological zone have not the same of land unit totals, suitability and problem for maize cultivation. For more details, it is presented in Table 2 .

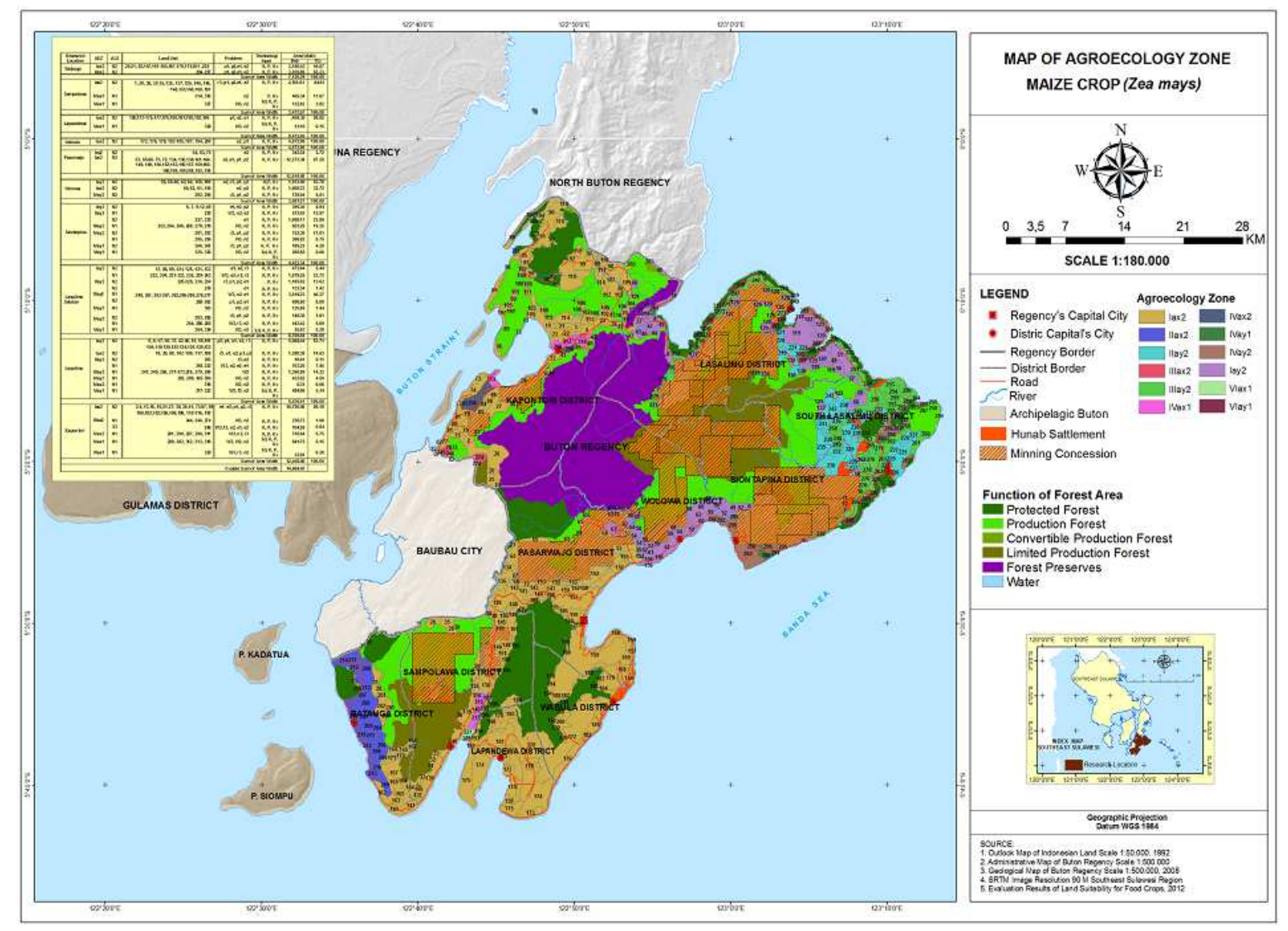

Figure 3. Map of Land Units and Agroecological Zoning for Maize Cultivation in Buton Regency 
Table 2. Results of Agroecological Zoning for Maize Cultivation in Buton Regency

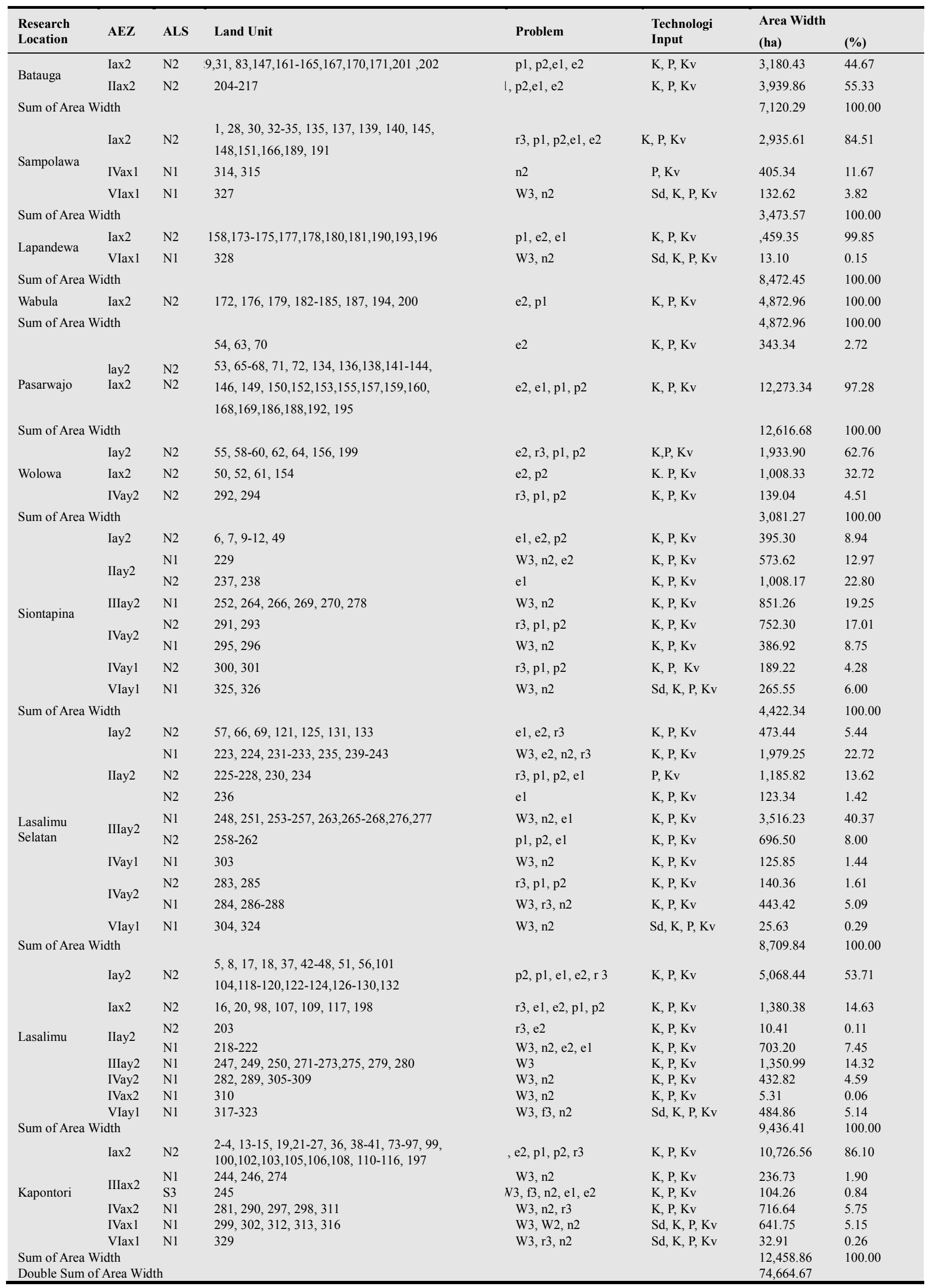




\subsection{Land Suitability Analysis}

Results for land suitability analysis (actual suitability and input technology) and map of agroecological zonation for maize cultivation at 10 research locations (sub-districts) in main land of Buton regency can be seen in Table 3 Fig. 4.

Table 3. Results for actual land suitability analysis of maize

\begin{tabular}{|c|c|c|c|c|c|c|c|}
\hline \multirow{2}{*}{ No. } & \multirow{2}{*}{ Research Location } & \multirow[b]{2}{*}{ S1 } & \multicolumn{5}{|c|}{ Class for Actual Land Suitability (ha) } \\
\hline & & & S2 & S3 & N1 & N2 & Total \\
\hline 1 & Batauga & - & - & - & - & $7,120.29$ & $7,120.29$ \\
\hline 2 & Sampolawa & - & - & - & 537.96 & $2,935.61$ & $3,473.57$ \\
\hline 3 & Lapandewa & - & - & - & 13.10 & $8,459.35$ & $8,472.45$ \\
\hline 4 & Wabula & - & - & - & - & $4,872.96$ & $4,872.96$ \\
\hline 5 & Pasarwajo & - & - & - & - & $12,616.68$ & $12,616.68$ \\
\hline 6 & Wolowa & - & - & - & - & $3,081.27$ & $3,081.27$ \\
\hline 7 & Siontapina & - & - & - & $2,077.35$ & $2,344.99$ & $4,422.34$ \\
\hline 8 & Lasalimu Selatan & - & - & - & $6,090.38$ & $2,619.46$ & $8,709.84$ \\
\hline 9 & Lasalimu & - & - & - & $2,977.18$ & $6,459.23$ & $9,436.41$ \\
\hline 10 & Kapontori & - & - & 104.26 & $1,628.04$ & $10,726.56$ & $12,458.86$ \\
\hline \multicolumn{2}{|r|}{ Total } & - & - & 104.26 & $13,324.01$ & $61,236.40$ & $74,664.67$ \\
\hline
\end{tabular}

Source: GIS Analysis, 2012

From Table 3, it can be seen that out of 74,664.67 ha areas that land can be used to cultivate food crops in the research region of main land of Buton regency, there was only one land suitability class for maize cultivation, and that was only marginal suitability class (S3), covering areas of 104.26 ha $(0.14 \%)$ in Kapontori. Other locations were, in general, permanently not suitable (N2) $61,236.40$ ha $(82.02 \%)$, with the largest area was in Pasarwajo 12,616.68 ha (16.90\%). Meanwhile, the area that was currently not suitable (N1) was 13.324.01 ha $(17.85 \%)$ with the largest area was in South Lasalimu 6,090.38 ha (8.016\%) (see Fig. 4).

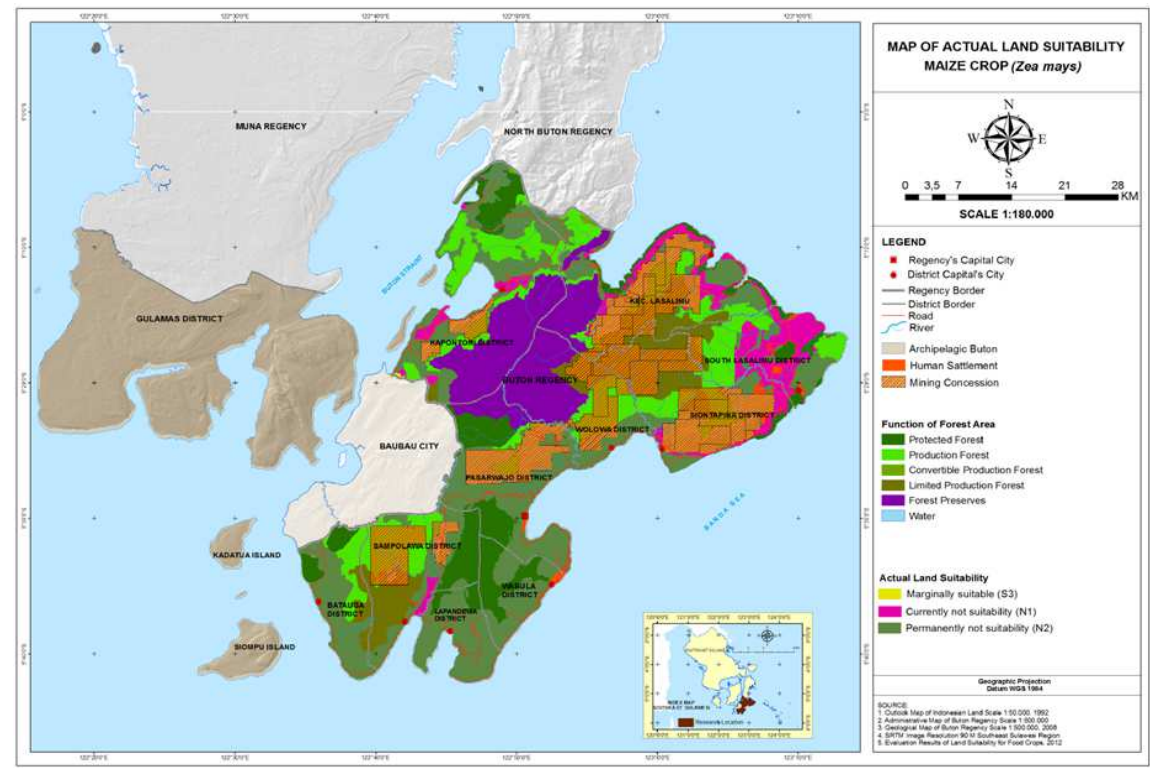

Figure 5. Map of Actual Land Suitability for Maize at 10 Sub-Districts in the Main Land of Buton Regency

\subsection{Discussion}

Research results indicated that research locations in the main-land area of Buton regency were diversed in soil, climate, and physiographic characteristics. The research findings indicated that regional zonation using a spatial method could effectively determine the agroecological potencies of a certain region therefore eased the planning and determination of proper cultivated food crops or other relevant purposes that were based on the principles of usefulness and sustainability. As noted in [15] agricultural production environments vary by climate (function of latitude, altitude, and other factors), soil and related aspects, consumer and producer preferences, accessibility, and input use, among other things. Similar results had been reported 
by [31] and [8] that the spatial method using GIS can be used to evaluate the characteristics of land potencies, so it helped us in making plans for crop cultivation. In term of soil and climate characteristics over the research region, all research sites had different characteristics. This indicated that the possibility and suitability levels of each research location for maize cultivation were diferred. According to Lieth in [18], important natural factors as indicators for land characteristics in a certain region, in relation to plans for crop development were climate characteristics, such as solar radiation, air temperature, evapotranspiration, and rainfall (precipitation). This means that information on climate characteristics was an important factor for determination of areas for maize cultivation. Additionally, [17] explained that soil and climate significantly contribute to the plant growth process.

Land suitability data showed that the research locations were in general unsuitable for maize cultivation, or at most marginally suitable (S3) for a total of only about 509.60 ha, in Sampolawa 405.34 ha and in Kapontori 104.26 ha. This fact was closely related to the dry climatic condition in the research region, with average yearly rainfall below $2000 \mathrm{~mm}$. In this condition, maize crops were unable to grow and produce optimally due to lack of water. Akdemir et al. [1] explained that the climate conditions were the most influencing agricultural factors, especially during growth period and seed formation or production phases. Similar arguments were also stated by [4], that climatic changes and its variation, especially rainfall, influenced the productivity of crop plants, particularly for gramineae, leguminoseae, and vegetables. Peter and Thorntonb [22] explained that the impacts of climate change on agriculture may add significantly to the development challenges of ensuring food security and reducing poverty. The unsuitability of most land areas for crop cultivation was also closely related to the interaction between land use and climate changes. Rounsevell and Reay [24] stated that the uneffective land use was due to climate change, or reversely it was also possible that wrongly use of land could cause climate change. This indicated that the unsuitability of a certain area for cultivation of a certain plant commodity was closely related to its climate and land conditions [16]. Crops will eventually not productive if they were forcely grown in an unsuitable location, except if improvements, including technology inputs, were made [20]. In agricultural context, finding optimal locations for crops can increase economic benefits, as well as reduce negative environmental consequences. The effectiveness of agricultural interventions - improved cultivars, agronomic management practices, decision support systems - depends on these factors.

\section{Conclusions}

From the results of this reserach, the following conclusions can be drawn:

a. Buton regency has various levels of land characteristics, physiography, and land use. Annual rainfall is generally low as classified as dry climate (average annual rainfall of less than $2000 \mathrm{~mm}$ ), distributed in three agroclimate zones: C3, D3, and E3.

c. There are 12 agroecologycal zones in the main land of Buton regency, i.e: Batauga (Iax2, IIax2), Sampolawa (Iax2, IVax1, VIax1), Lapandewa (Iax2, VIax1), Wabula (Iax2), Pasarwajo (Iay2, Iax2), Wolowa (Iay2, Iax2, IVay2), Siontapina (Iay2, IIay2, IIIay2, IVay1, IVay2, VIay1), Lasalimu Selatan (Iay2, IIay2, IIIay2, IVay1, IVay2, VIay1), Lasalimu (Iay2, Iax1, IIay2, IIIay2, IVay1, IVax2, VIay1), Kapontori (Iax2, IIIax2, IVax1, IVax2, VIax1). that Such variation eventually influences land suitability level for the maize cultivation and development.

d. There was limited area of potential dryland for cultivation and development of maize in Buton regency. The area only has land class of marginal suitable (S3) for maize cultivation, about 509.60 ha or $0.64 \%$ from a total of $74,664.67$ ha potential cultivation area for cropping. This marginal suitable land (S3) was located in Sampolawa 405.34 ha $(0.54 \%)$ and Kapontori 104.26 ha $(0.14 \%)$. Other locations were in general classified as permanently not suitable (N2) $61,113.08$ ha $(81.85 \%)$, the largest is in Pasarwajo $12,616.68$ ha $(16.90 \%)$, and currently not suitable (N1) $13,042.01$ ha $(17.47 \%)$, the largest is in South Lasalimu 6,5459.23 ha (8.32\%).

\section{Acknowledgment}

We would like to thank the Government of Buton Regency, Local Government Institutions, and Buton society for their generoucity of giving important data for the research. Special acknowledgement is also delivered to the Rector and the Head of Research Institution of Haluoleo University for providing research fund through the grant of BOPTN Unhalu 2012/2013. GIS facility supports from GIS Laboratory, Faculty of Forestry, Haluoleo University, and spatial data provided by the Center for Regional Development and Spatial Information (WITARIS), Hasanuddin University are highly appreciated.

\section{References}

[1] Akdemir S., H. Akcaoz, H. Kizilay, and A. Ozalp. 2012. Impacts of climate factors on wheat yields in Turkey. Journal of Food. Agriculture \& Environment, Vol. 10 (2): 398-402. WFLPublizer, Science and Technology. Helzinki Finland.

[2] Ande, O.T. 2011. Soil suitability evaluation and management for cassava production in the derived savanna of South Western Nigeria. International Journal of Soil Science. 6(2):142-149. Academic Journals Inc.

[3] Ashraf S., H. Afshari, R. Munokyan, and A. G. Ebadi. 2010. Multicriteria land suitability evaluation for barley by using GIS in damghan plain (Northeast of Iran). Journal of Food, Agriculture \& Environment Vol.8 (3\&4): 626-628. 2010. WFL Publisher, Science and Technology. Meri-Rastilantie 3 B, FI-00980. Helsinki, Finland, e-mail: info@world-food.net. 
[4] Awotoye, O. O. and O. J. Matthew. 2009. Effects of temporal changes in climate variables on crop production in tropical sub-humid South-Western Nigeria. Journal of Agriculture, Biotechnology \& Ecology, 2(3), 408-419, 2009. ISSN: 20063938.

[5] Baja, S. 2001. The Quality of the land : Using GIS for continuous-based land suitability assessment in the Sydney Region. GIS User, 44: 32-33.

[6] Baja, S. 2012. Perencanaan tata guna lahan dalam pengembangan wilayah: Pendekatan spasial dan aplikasinya. Penerbit ANDI, Yogyakarta.

[7] Baja, S. 2012a. The Sleeping Giant. Buton Raya. Isyarat ilmiah menguak takbir tujuh. Penerbit. Pemda Kota Bau-Bau Kerjasama dengan Puslitbang Witaris, Universitas Hasanuddin, Makassar.

[8] Baja, S. 2012b. Metode analitik evaluasi sumber daya lahan: Aplikasi GIS, Fuzzy Set, dan MCDM. Penerbit: IDENTITAS. Universitas Hasanuddin, Makassar.

[9] [Bappeda] Badan Perencanaan Pembangunan Daerah Kabupaten Buton. 2010. Penyusunan master plan kawasan pengembangan sektor unggulan (Agromarine) Kabupaten Buton. ALBUM PETA (Buku II). Bappeda Buton.

[10] [Bakosurtanal] Badan Koordinasi Survey dan Pemetaan Nasional. 2010. Atlas Nasional Indonesia. Fisik dan Lingkungan Alam (Volume 1). Potensi dan sumberdaya, sejarah, wilayah, penduduk, dan budaya. Bakosurtanal, Jakarta.

[11] [BPS Buton] Badan Pusat Statistik Kabupaten Buton. 2011. Kabupaten Buton dalam Angka. Pasarwajo: BPS Kab. Buton.425 hal. Dicetak oleh: CV. Kainawa Molagina BauBau.

[12] Djaenudin, D., Marwan H., dan A. Hidayat. 2003. Petunjuk teknis evaluasi lahan untuk komoditas pertanian. Versi 3. 2000. Balai Penelitian Tanah, Puslitbang Tanah dan Agroklimat, Bogor.

[13] Djaenudin, D. 2009. Prospek penelitian potensi sumberdaya lahan di wilayah Indonesia. Journal Pengembangan Inovasi Pertanian 2(4): 2009 243-257. Balai Besar Penelitian dan Pengembangan Sumberdaya Lahan Pertanian, Jalan Ir. H. Juanda No. 98, Bogor 16123.

[14] [FAO] Food Agricultural Organization. 1976. A Framework for land evaluation. FAO Soils Bulletin No.32, Food and Agriculture Organisation of the United Nations, Rome.

[15] Hartkamp, A.D., J.W. White, A. Rodríguez Aguilar, M. Bänziger, G. Srinivasan, G. Granados, and J. Crossa. 2000. Maize production environments revisited: A GIS-based approach. Mexico, D.F.: CIMMYT.

[16] Joshi, N.Prakash, Maharjan, K. Lall, P. Luni. 2011. Effect of climate variabels on yield of major food-crops in Nepal. Journal of Contemporary India Studies: Space and Society Studies and Society. Hiroshima University.
[17] Lavalle, C., Micale F., Houston T. D., Camia A., Hiederer R., Lazar C., Conte C., Amatulli G., Genovese G. 2009. Climate change in Europe. Impact on agriculture and forestry. A. Review, Agron. Sustain. Dev. 29, 433-446.

[18] Mueller, L.U. Schindler, W. Mirschel., T.G. Shepherd, B.C. Ball., K. Helming., J. Rogasik, F. Eulenstein, H. Wiggering. 2010. Assesing the productivity functions of soils. A Review. Agron. Sustain. Dev. 30. 601-614. INRA.EDP. Sciences.

[19] Mulyani, A. 2001. Petunjuk teknis penyusunan peta pewilayahan komoditas pertanian berdasarkan zona agroekologi skala 1:50.000. Pusat Penelitian dan Pengembangan Tanah dan Agroklimat. Bogor.

[20] Niggol, S. R., Mendelsohn, Pradeep, Kurukulasuriya, A.Dinar, Rashid, Hassan. 2008. Differential adaptation strategies to climate change in African cropland by agro-ecological zones. Policy Research Working Paper, 4600. The World Bank evelopment Research Group Sustainable Rural and Urban Development Team. April 2008.

[21] Oldeman, L.R. 1975. An agro-climate map of Java, Central research Institute for Agriculture, Bogor, No. 17.

[22] Peter G. J. and P.K. Thorntonb. 2003. The Potential impacts of climate change on maize production in Africa and Latin America in 2055. Global Environmental Change 13 (2003) $51-59$.

[23] Rossiter, D.G. 1994. Land evaluation. Cornell University College of Agr \& Life Sciences Department of Soil, Crop \& Atmospheric Science, Australia.

[24] Rounselvell M.D.A., and D.S. Reay. 2009. Land use and climate change in UK. Land Use Policy 26S, S160-S169. Elsevier.

[25] Siderius, W. 1986. Land evaluation for land-use planning and conservation in sloping areas, Netherlands: International Institute For Land and Improvement.

[26] Soekardi, M. 1993. Mengenal peta tanah. Pusat Penelitian Tanah dan Agroklimat. Bogor.

[27] Soekarman, 1993. Pengamatan tanah di lapang. Pusat Penelitian Tanah dan Agroklimat Bogor. Bogor.

[28] Soil Survey Division Staff, 1993. Soil survey manual. USDA Handbook No.18. United States Department of Agriculture, Washington DC.

[29] Soil Survey Laboratory Staff, 1991. Soil survey laboratory methods manual. SCS-USDA. October 1991; 611p.

[30] Soil Survey Staff. 2010. Keys to soil taxonomy. Eleventh Edition. United States Department of Agriculture,Natural Resources Conservation Service. Washington DC.

[31] Wirosoedarmo R., A. T. Sutanhaji, E.Kurniati dan R. Wijayanti. 2011. Evaluasi kesesuaian lahan untuk tanaman jagung menggunakan metode analisis spasial. Journal AGRITECH, Vol. 31, No. 1, Februari 2011. Fakultas Teknologi Pertanian, Jurusan Keteknikan Pertanian, Universitas Brawijaya, Jl. Veteran Malang 65145. 